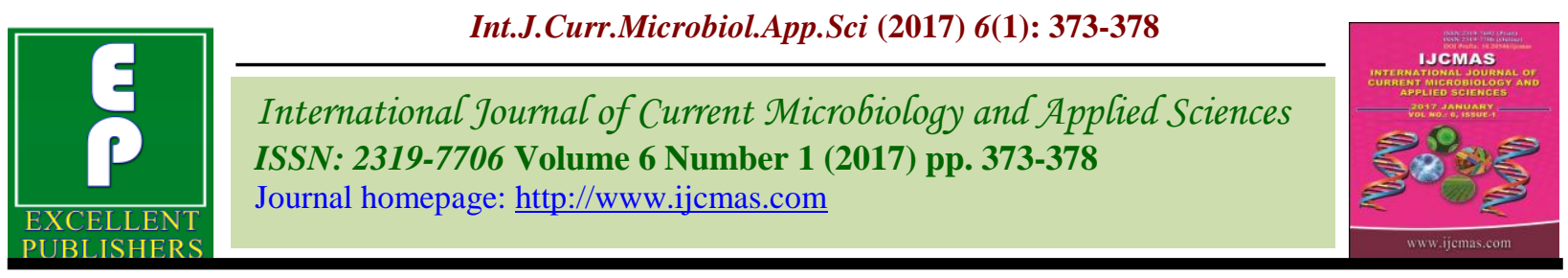

Original Research Article

http://dx.doi.org/10.20546/ijcmas.2017.601.045

\title{
Seed Borne Mycoflora of Macrotyloma uniflorum L (Horse gram)
}

\author{
D. Sai Kumari* and Neeti Saxena \\ Mycology and Plant pathology, Department of Botany, University College for Women, \\ Koti, Osmania University, Hyderabad, Telangana, India \\ *Corresponding author
}

\begin{tabular}{|c|c|}
\hline & A B S T R A C T \\
\hline Keywords & \multirow{4}{*}{$\begin{array}{l}\text { Horse gram (Macrotyloma uniflorum), belongs to the family Fabaceae is one of the minor } \\
\text { or lesser known neglected legume mainly cultivated due to high levels of protein. It is } \\
\text { considered as poor man's pulse. Horse gram has an excellent nutritional, therapeutic and } \\
\text { medicinal properties. Field variety of horse gram seeds were collected from the Indurthi } \\
\text { village, Kharimnagar district, Telangana, India. The legume seed borne fungi was screened } \\
\text { by employing blotter paper method, agar plate method and dilution plate method. The } \\
\text { untreated seeds were found to be associated with the highest number of seed borne } \\
\text { fungi.64 species and } 32 \text { genera were isolated. Among them Alternaria spp, Aspergilllus } \\
\text { spp, Cheatomium spp, Cladosporium spp, Curvularia spp, Drechslera spp, Fusarium spp, } \\
\text { Mucor spp, Pencillium spp, Rhizopus spp, Trichodrma spp were dominant species isolated } \\
\text { from the three methods. In all the three methods blotter method had recorded most of the } \\
\text { fungal species than the other two methods. }\end{array}$} \\
\hline $\begin{array}{l}\text { Horse gram, seed } \\
\text { borne fungi, } \\
\text { untreated seeds, } \\
\text { blotter method, } \\
\text { Karimnagar. }\end{array}$ & \\
\hline Article Info & \\
\hline $\begin{array}{l}\text { Accepted: } \\
\text { 20 December } 2016 \\
\text { Available Online: } \\
\text { 10 January } 2017\end{array}$ & \\
\hline
\end{tabular}

\section{Introduction}

Food legumes are second most important group of crops after cereals which have been a vital ingredient of balanced human diet since millennia (Bhadana et al., 2013) and recognized as second most valuable plant source for human and animal nutrition (Bhatt and Karim, 2009; Bhartiya et al., 2015). The world's stored grain is damaged mainly by the activity of fungi than other microorganism was stated by Neergard, (1977). Seeds play a vital role in the production of healthy crops. Healthy seed is the foundation of healthy plant; a necessary condition for good yields (Diaz et al., 1998).Seeds that were infected or contaminated with pathogens (Agarwal, 1976). Seed-borne diseases have been found to affect the growth and productivity of crop plants (Kubiak and Korbas, 1999; Weber et al., 2001; Dawson and Bateman, 2001). Presence or absence of seed borne fungi on seed surface is one of the important aspects that determine the quality of seed.

Horsegram belongs to family Fabaceae is a potential grain legume having excellent nutritional and remedial properties with better climate resilience to adapt harsh environmental conditions (Kumar, 2006). It is one of the most important unexploited food legume being grown in almost all over the world including temperate and sub-tropical regions encompassing the countries in East and Northeast Africa, Asian countries particularly, India, China, Philippines, 
Bhutan, Pakistan, Sri Lanka and Queensland in Australia (Durga, 2012; Krishna, 2010). Horsegram [Macrotyloma uniflorum (L.) Verdc] has great significance in the nutritional security of rural, tribal and underprivileged masses (Tontisirin, 2014). Horse gram is one of the highly nutritious vegetable pulse crop with ethno-medicinal values in India, which is commonly known as Kulattha (Sanskrit), Kurti-kalai(Bengali), Kollu (Tamil), Ullavallu (Telgu), Muthira (Malyalam), Gahot(Kumaon and Garhwal) and etymologically, Gahotmeans "which destroys stone in initial stage" (Pati and Bhattacharjee, 2013; Pande, 1999).

Horsegram is a short day, twining, succulent, annual climbing herb which has trifoliate leaves, white coloured flowers, long linear pubescent pods with curved beak, flattened small seeds with light red, brown, grey, black or mottled testa (Singh, 1991) with photo andthermo sensitive nature (Kumar, 2006). It is mostly grown as catch crop especially under late summer (Kharif) or with the rains after a prolonged drought condition (Prakash et al., 2002).

In the present study an attempt was made to find out the fungi which is associated with the seeds of horse gram.

\section{Materials and Methods}

The field variety of horse gram seeds were collected from the Indurthi village, Kharimnagar district, Telangana, India. The collected seeds were stored in cloth bags for six months at room temperature for the study of storage fungi.Isolation of seed mycoflora was done by blotterMethod (De Tempe, (1953). Agar plate method by Muskett, (1948) and Dilution plate method by Peterson, (1959). These investigations were carried out in freshly harvested seeds samples as well as during their subsequent storage at an interval of 30 days for six months.

\section{Results and Discussion}

64 fungal species with 32genera were isolated from the table.1.Alternaria alternata, Aspergillus flavus, Aspergillus flaviceps, Aspergillus fumigatus, Aspergillus candidus, Cheatomium globossum, Cheatomium herbarum, Cheatomium murorum, Cladosporium spp, Curvularia lunta, Drechslera halodes, Fusarium moniliforame, Fusarium roseum, Macrophominaphaseolina, Mucor varians, Mucor racemosus, Nigrospora sphaerica, Pencillium chrysogenum, Pencillium citrinum, Phomaspp, Rhizopus stolonifera, Rhizopus nigricans, Trichoderma hamatum, Trichoderma viridae, Trichoderma album, Verticillium sps. Were the dominant species.

Among the 3 methods in Agar method most of the fungi were isolated fallowed by Blotter method and dilution plate technique.

Seed is the most important input for crop production. Pathogen free healthy seed is urgently needed for desired plant populations and good harvest (Narayan et al., 2013). Many plant pathogens are seed-borne, which can cause enormous crop losses; reduction in plant growth and productivity of crops (Kubiak and Korbas, 1999; Dawson and Bateman, 2001; Islam et al., 2009).

Neetisaxena et.al, 2015reported that Fungi have assumed great economic significance, as they not only cause spoilage of grains, during pre and post-harvest stages of production, but also produce various toxins (mycotoxins).

Delouch et al., (1973) stated that fungi were the major deteriorating agents which are known to affect the capacity of seeds togerminate, besides discoloring the parts, loss in luster, heating, mustiness and changes in oil content, free acids and protein content etc. 
Table.1

\begin{tabular}{|c|c|c|c|c|c|c|c|}
\hline \multirow{3}{*}{ S. No } & \multirow{3}{*}{ Mycoflora } & \multicolumn{6}{|c|}{ Horse gram seeds } \\
\hline & & \multicolumn{2}{|c|}{ B.M } & \multicolumn{2}{|c|}{ AGP.M } & \multicolumn{2}{|c|}{ DP.M } \\
\hline & & $\mathrm{U}$ & $\mathrm{S}$ & $\mathrm{U}$ & $\mathrm{S}$ & $\mathrm{U}$ & $\mathrm{S}$ \\
\hline 1. & Alternaria alternate & + & + & + & + & + & + \\
\hline 2. & Alternaria humicola & + & + & + & - & + & + \\
\hline 3. & Alternaria tenuis & + & + & + & - & + & - \\
\hline 4. & Alternaria pori & + & - & + & + & + & + \\
\hline 5. & Aspergillus flavus & + & + & + & + & + & + \\
\hline 6. & Aspergillus flavipes & + & + & + & + & + & + \\
\hline 7. & Aspergillus fumigatus & + & + & + & + & + & + \\
\hline 8. & Aspergillus candidus & + & + & + & + & + & + \\
\hline 9. & Aspergillus niger & + & - & + & + & + & - \\
\hline 10. & Aspergillus nidulans & + & - & + & + & + & - \\
\hline 11. & Aspergillus ochraceus & + & - & + & + & - & - \\
\hline 12. & Aspergillus sulphureus & - & - & + & + & - & - \\
\hline 13. & Aspergillus sydowii & - & - & + & + & - & - \\
\hline 14. & Aspergillus tamarii & - & - & - & + & + & + \\
\hline 15. & Aspergillus terreus & + & - & + & + & - & - \\
\hline 16. & Aspergillus versicolor & + & - & + & - & + & - \\
\hline 17. & Aspergillus carbonarius & + & - & - & - & + & - \\
\hline 18. & Botrytis sp. & + & - & + & + & - & - \\
\hline 19. & Cephalosprium $s p$ & + & + & + & - & + & - \\
\hline 20. & Cercospora spp & + & - & + & - & - & - \\
\hline 21. & Chaetomium cochloides & + & - & + & - & + & - \\
\hline 22. & Chaetomium globosum & + & + & + & + & + & + \\
\hline 23. & Chaetomium herbarum & + & + & + & + & + & + \\
\hline 24. & Chaetomium murorum & + & + & + & + & + & + \\
\hline 25. & Cladosporium sp & + & + & + & + & + & + \\
\hline 26. & Curvularia lunata & + & + & + & + & + & + \\
\hline 27. & Colletotrichumtruncatum & - & - & + & - & + & - \\
\hline 28. & Drechslera hawaiiensis & + & - & - & - & + & - \\
\hline 29. & Drechslera holodes & + & + & + & + & + & + \\
\hline 30. & Drechslera tetramera & + & - & + & - & + & - \\
\hline 31. & Fusarium moniliforme & + & + & + & + & + & + \\
\hline 32. & Fusarium Oxysporum & - & + & - & - & + & + \\
\hline 33. & Fusarium roseum & + & + & + & + & + & + \\
\hline 34. & Fusarium solani & + & + & + & - & + & - \\
\hline 35. & Fusarium equiseti & - & - & + & - & + & - \\
\hline 36. & Fusarium semitecum & - & - & - & + & - & - \\
\hline 37. & Helminthosporiumsp. & - & - & + & - & + & + \\
\hline 38. & Humicola sp. & - & - & + & - & - & - \\
\hline 39. & Macrophomina phaseolina & - & + & + & + & + & + \\
\hline 40. & Monilia sitophila & + & - & - & - & + & - \\
\hline
\end{tabular}




\begin{tabular}{|l|l|l|l|l|l|l|l|}
\hline 41. & Mucor varians & + & + & + & + & + & + \\
\hline 42. & Mucor hiemalis & - & - & + & - & + & - \\
\hline 43. & Mucor racemosus & + & + & + & + & + & + \\
\hline 44. & Myrothecium roridum & + & - & - & - & + & - \\
\hline 45. & Nigrospora sphaerica & + & + & + & + & + & + \\
\hline 46. & Penicillium chrysogenum & + & + & + & + & + & + \\
\hline 47. & Penicillium citrinum & + & + & + & + & + & + \\
\hline 48. & Penicillium notatum & + & - & + & + & + & - \\
\hline 49. & Periconia spp & + & - & + & - & + & - \\
\hline 50. & Phoma sp & + & + & + & + & + & + \\
\hline 51. & Pythium spp & - & - & - & - & + & - \\
\hline 52. & Rhizoctonia bataticola & + & - & + & - & + & - \\
\hline 53. & Rhizopus nigricans & + & + & + & + & + & + \\
\hline 54. & Rhizopus stolonifera & + & + & + & + & + & + \\
\hline 55. & Rhizopus nodosus & + & - & + & - & + & - \\
\hline 56. & Stachybotrysatra & + & - & + & - & - & - \\
\hline 57. & Syncephalastrum sp & + & - & + & - & + & - \\
\hline 58. & Sclerotiumsp & + & - & + & - & + & - \\
\hline 59. & Scopularopsis sp. & + & - & + & - & - & - \\
\hline 60. & Trichoderma hamatum & + & + & + & + & + & + \\
\hline 61. & Trichoderma viridae & + & + & + & + & + & + \\
\hline 62. & Trichothecium roseum & + & + & + & - & - & - \\
\hline 63. & Trichoderma album & + & + & + & + & + & + \\
\hline 64. & Verticillium sp & + & + & + & + & + & + \\
\hline & & & & & & \\
\hline
\end{tabular}

U- Unsterilized, S- Surface sterilized, B.M- Blotter, AGP.M- Agar plate and DP.M- Dilution Plate Method.

Seed borne Mycoflora plays an important role in determining the quality and longevity of seeds. Microbial invasions can lead to the rotting and loss of seed viability, vigour, germination and oil quality Nagaraja and Krishnappa, (2009); Neetisaxena et al., 2015) The variation was observed in seed mycoflora from freshly stage to atthe end of the storage period. Storage fungi were present in low percentage in freshly harvest seed samples and became dominant as the storage period increased. Storage fungi require high osmotic pressure and no water (Manoharachary and Kunwar, 2006).

In conclusion, in the present investigation seed associated mycoflora were isolated by the three methods blotter method, agar plate method and dilution plate method. Among them Agar plate method had recorded more fungi than the other two methods. Alternaria spp, Aspergilllus spp, Cheatomium spp, Cladosporium spp, Curvularia spp, Drechslera spp, Fusarium spp, Mucor spp, Pencillium spp, Rhizopus spp, Trichodrma spp were dominant species isolated from the three methods. Storage fungi is in low percentage than the field fungi.

\section{Acknowledgement}

I sincerely thank UGC for providing NONNET fellowship through the Department of Botany, University College of Science, Osmania University, Hyderabad, Telangana state, India. 


\section{References}

Bhartiya, A., J.P. Aditya and L. Kant. 2015. Nutritional and remedial potential of aunderutilized food lugeme horse gram (Macrotyloma uniflorum): A Review $J$. Ani. Plant Sci., 25(4): 2015, Page: 908920 ISSN: 1018-7081

Agrawal, P.K. 1976. Identification of suitable seed storage places in India on the basis of temperature and relative humidity condition. Seed Res., 4(1): 6-11.

Bhadana, V.P., P.K. Sharma, M.A. Ansari , L.K. Baishya, P. Punetha, S. Datt, N. Prakash, and K.S. Rana. 2013. Food legumes for livelihood and nutritional security in North Eastern Himalayan region: Prospects and constraints. Indian J. Agricultural Sci.. 83(9): 899. 906.

Bhatt, R. and A.A. Karim. 2009. Exploring the nutritional potential of wild and underutilized legumes. Comprehensive Reviews in Food Science and Food Safety, 8: 305-331.

Bornefungi. Trans. Brit. Mycol. Soc., 39: 7483.

Dawson, W.A.J.M. and Bateman, G.L. 2001. Bateman.Fungal communities on roots of wheat and barley and effects of seed treatments containing fluquinconazole applied to control take-all. Plant PathoL., 50: 5-82.

De Tempe, J. 1953. The blotter method of seed health testing. Proc. ISTA. 26: 133151.

Delouche, J.C., and Baskin, C.C. 1973. Seed Sci. Technol., 1: 427-452.

Diaz, C., Hossain, M., Bose, M. L., Mercea, S. and Mew, T.W. 1998. Seed quality and effect on rice yield: findings from farmer sparticipatory experiment in Central Luzon,Philippines. J. Crop. Sci. 23(2):111-119.
Durga, K.K. 2012. Variability and divergence in horsegram (Dolichosuniflorus). $J$. Arid Land, 4(1): 71-76.

Islam, S.M.M., Masum, M. M. I. and Fakir, M.G.A. 2009. Prevalence of seed-borne fungi in sorghum of different locations of Bangladesh. Scientific Res. Essay, 4(3): 175-179

Krishna, K.R. 2010. Legume agro ecosystems of south India: nutrient dynamics, ecology and productivity. Brown Walker Press, Florida, USA. 372-382 pp.

Kubiak, K. and Korbas, M. 1999. Occurrence of fungal diseases on selected winter wheat cultivars. Postepy Ochronie Roslin, 39 (2): 801-804

Kumar, D. 2006. Horsegram research: An introduction. In: Kumar D. (Ed.), Horsegram in India.1-10 pp.

Manoharachary, C. \& I.K. Kunwar. 2006. Seed borne fungal pathogens of Soybean. J. Basic Appl. Mycol., 5(I\&II):1-8.

Muskett, A.E. 1948. Technique for the examination of seeds for the presence of seed.

Nagaraja, O. and M. Krishnappa. 2009. Seed borne mycoflora of niger (Guizotiaabyssinicacass,) and its effect on germination. Phytopathol., 62(4): 513-517.

Narayan, M., Ghangaokar and Ayodhya, D. Kshirsagar. 2013. Study of seed borne fungi of different legumes. ISSN: 23194731.

Neergaard, P.1977. Seed Pathology(ed). The Mc Millan press. London.

Neeti Saxena, S.K. Shiva Rani and M. Deepika. 2015. Biodeterioration of Soybean (Glycine max L.) seeds during storage by Fungi Int. J. Curr. Microbiol. App. Sci., 4(6): 1118-1126.

Pande, P.C. 1999. Kumaonmeinprachalit perpaudhonkesthaniyanamokivyautpatti. In Ethnobotany of Kumaon Himalaya. In: 
Pande PC, Pokharia DS and Bhatt JC (Eds) Scientific Publishers, Jodhpur, (India) 253-262 pp.

Pati, C.K. and A. Bhattacharjee. 2013. Seed potentiation of a horsegram cultivar by herbal manipulation. Int. J. Med. Plants Res., 2(1):152-155.

Peterson, 1959. Seed borne fungi in relation to colonization of roots. Canad. J. Microbiol., 6: 579-582.

Prakash, B.G., N.Y. Nayakar and M.B. Glue. 2002. KBHG1-Promising horsegram variety for Northern Dry Zone of Karnatka. Karnataka J. Agric. Sci., 15(2): 362-363.
Singh, B. and Singh, U. 1991. Peanut as a Source of Protein for Human Foods. Plant Food for Human Nutri., 41, 165177.

Tontisirin, K. 2014. Promotion of underutilized indigenous food resources for food security and nutrition in Asia and the Pacific. In: Durst $P$ and Bayasgalanbat N (Eds) 21-25 pp.

Weber, R.B., Hrynczuk, B., Runowska Hrynczuk, Kita, B. 2001. Influence of the mode of tillage on diseases of culm base in some winter wheat varieties, oats, and spring wheat. J. Phytopathol., 149: $185-188$.

\section{How to cite this article:}

Sai Kumari, D., and Neeti Saxena. 2017. Seed borne Mycoflora of Macrotyloma uniflorum L (Horse gram). Int.J.Curr.Microbiol.App.Sci. 6(1): 373-378. doi: http://dx.doi.org/10.20546/ijcmas.2017.601.045 